\title{
Effect of Metalloid and Metal Oxide Nanoparticles on Fusarium Wilt of Watermelon
}

\author{
Wade Elmer, ${ }^{\dagger}$ Department of Plant Pathology and Ecology, The Connecticut Agricultural Experiment Station, New Haven; Roberto De La \\ Torre-Roche, Department of Analytical Chemistry, The Connecticut Agricultural Experiment Station, New Haven; Luca Pagano, Department \\ of Chemistry, Life Sciences and Environmental Sustainability, University of Parma, 43124 Parma, Italy; Sanghamitra Majumdar and Nubia \\ Zuverza-Mena, Department of Analytical Chemistry, The Connecticut Agricultural Experiment Station; Christian Dimkpa, International \\ Fertilizer Development Center, Muscle Shoals, AL, 35662; Jorge Gardea-Torresdey, Department of Chemistry and Biochemistry, The Uni- \\ versity of Texas at El Paso 79968; and Jason C. White, Department of Analytical Chemistry, The Connecticut Agricultural Experiment Station
}

\begin{abstract}
This study explored the use of foliar sprays with nanoparticles (NP) of B, $\mathrm{CuO}, \mathrm{MnO}, \mathrm{SiO}, \mathrm{TiO}$, and $\mathrm{ZnO}$ to protect watermelon against Fusarium wilt. Leaves of young watermelon plants were sprayed ( 1 to $2 \mathrm{ml}$ per plant) with NP suspensions (500 to $1,000 \mu \mathrm{g} / \mathrm{ml}$ ) and were planted in potting mix infested with Fusarium oxysporum $\mathrm{f}$. sp. niveum. In five of eight greenhouse experiments, $\mathrm{CuO} \mathrm{NP}$ suppressed disease and, in six of eight experiments, $\mathrm{CuONP}$ increased biomass or yield more than in untreated controls or other tested NP. More root $\mathrm{Cu}$ was detected in $\mathrm{CuO}$ NP-treated plants than other

treatments $(P=0.015)$. In Griswold, $\mathrm{CT}$, plants treated with $\mathrm{CuO}$ NP yielded $39 \%$ more fruit than untreated controls. In Hamden, CT, treatment with $\mathrm{CuO}$ NP produced $53 \%$ more fruit when compared with controls $(P=0.02)$ and was superior to other $\mathrm{Cu}$ fungicides. Gene expression in watermelon roots revealed strong upregulation of polyphenol oxidase (PPO) and PR1 genes when $\mathrm{CuONP}$ and $F$. oxysporum $\mathrm{f}$. sp. niveum were both present. Enzymatic assays for PPO supported the gene expression results. CuO NP may serve as a highly effective delivery agent for this micronutrient to suppress disease.
\end{abstract}

Engineered nanoparticles (NP) $(<100 \mathrm{~nm})$ of metalloid and metal oxides have great potential in agriculture as a means to deliver micronutrients to plants (Khan and Rizvi 2014; Servin et al. 2015). It is well documented that the micronutrients $\mathrm{B}, \mathrm{Cu}, \mathrm{Mn}$, and $\mathrm{Zn}$ can play pivotal roles in plant health by activating important enzyme systems such as those of phenol metabolism (Römheld and Marschner 1991). Because micronutrients, in general, have poor basipetal and intraplant mobility (Bukovac and Wittwer 1957) and are less available in neutral soils (Leeper 1952), compromised nutrition of the plant roots often results in increased susceptibility to wilts and root rots.

Past research from our groups demonstrated that $\mathrm{CuO} \mathrm{NP}$ and other metal oxide micronutrients possess the potential to fertilize roots when applied foliarly, presumably due to nano-enabled basipetal translocation. Both Wang et al. (2012) and Elmer and White (2016) provided evidence in support of basipetal translocation of $\mathrm{CuO}$ NP in eggplant, maize, and tomato. Using maize grown in split-root pots, Wang et al. (2012) detected increased $\mathrm{Cu}$ in unexposed roots following application of $\mathrm{CuO} \mathrm{NP}$ to one side. Tomato and eggplant roots had more $\mathrm{Cu}$ when the leaves were exposed to $\mathrm{CuO} \mathrm{NP}$ and had less disease when these plants were grown in soil with Fusarium oxysporum f. sp. lycopersici or Verticillium dahliae, respectively. The role of NP in delivering nutrition for disease management is otherwise largely unexplored.

The underlying mechanisms of $\mathrm{CuO} \mathrm{NP}$ on plants are not clear. The antifungal and antioomycete activities of $\mathrm{CuO}$ NP is known (Kanhed et al. 2014; Zabrieski et al. 2015), and recent discoveries with new engineered composites of $\mathrm{Cu}$ NP have been shown to be effective against $\mathrm{Cu}$-tolerant bacterial pathogens of tomato (Strayer-Scherer et al. 2018). However, the role of the nutritional effects of $\mathrm{CuO}$ NP on root disease suppression is still not clear (Servin et al. 2015). $\mathrm{Cu}$ is a cofactor for three important proteins: plastocyanins, peroxidases, and multi-Cu oxidases (Evans et al. 2007), many of which serve in the creation of host defense barriers (Chmielowska et al. 2010). One major group of

\section{${ }^{\dagger}$ Corresponding author: W. Elmer; E-mail: Wade.Elmer@ct.gov}

Funding: This study was funded through a United States Department of Agriculture National Institute for Food and Agriculture grant 2016-6702124985, Hatch grant CONH00647, and funds from the National Watermelon Association.

Accepted for publication 4 February 2018.

() 2018 The American Phytopathological Society enzymes are polyphenol oxidases (PPO) that show increased activity in the presence of $\mathrm{Cu}$ ions when attacked by pathogens (Evans et al. 2007; Mayer and Harel 1979). It is not known how CuO NP might influence the activity of these enzymes.

Fusarium wilt of watermelon (Citrullus lanatus var. lanatus (Thunb.) (Matsum. \& Nakai), caused by $F$. oxysporum f. sp. niveum, appears wherever watermelon is grown, including North America, Asia, Australia, Europe, and the Middle East (Everts and Himmelstein 2015). The incidence and severity of Fusarium wilt on watermelon has increased due to several factors. The loss of methyl bromide application (due to concerns over ecotoxicity), shorter rotations, and the advent of highly susceptible triploid seedless watermelon have resulted in widespread outbreaks in many areas where the disease had previously not been a problem (Egel and Hoke 2010; Everts and Himmelstein 2015; Wu et al. 2013). Recent improvements in grafting, cover cropping, and biological control have lessened damage from Fusarium wilt to some extent but additional management strategies are still needed (Everts and Himmelstein 2015; Ren et al. 2008).

The effect of metalloid or metal oxide NP on Fusarium wilt of watermelon are unknown. In this work, our objectives were, first, to examine the effect of several NP metalloid (B) and metallic oxides $(\mathrm{Cu}, \mathrm{Mn}$, $\mathrm{Si}, \mathrm{Ti}$, and $\mathrm{Zn}$ ) on plant growth and elemental root composition of watermelon plants, to evaluate the ability of the NP to suppress Fusarium wilt and affect plant growth and yield. Second, we examined the effect of increasing rates of $\mathrm{CuONP}$ on plant growth and Fusarium wilt. Our third objective was to compare $\mathrm{CuO} \mathrm{NP}$ with two commercial forms of $\mathrm{Cu}$ fungicides for effect on yield and disease control. Our fourth objective was to explore the effect of $\mathrm{CuO} \mathrm{NP}$ on the expression and activity of PPO using transcriptomics and enzymatic assays.

\section{Materials and Methods}

Greenhouse experiments. The first two greenhouse experiments were conducted to address objective 1 and screen several NP for their ability to affect plant growth and Fusarium wilt. For greenhouse experiment 1 , foliar sprays of $\mathrm{NP}$ suspensions of $\mathrm{CuO}(30 \mathrm{~nm}), \mathrm{MnO}$ $(40 \mathrm{~nm}), \mathrm{SiO}$ (20 to $30 \mathrm{~nm}), \mathrm{TiO}_{2}(30 \mathrm{~nm}$, rutile), and $\mathrm{ZnO}$ (10 to $30 \mathrm{~nm}$ ) were applied to watermelon plants and compared with untreated watermelon plants for effects on biomass and Fusarium wilt. Watermelon seed (cultivar Sugar Baby; Harris Seed Co., Rochester, NY) were germinated on 19 March in 36-cell (5.66 by 4.93 by $5.66 \mathrm{~cm}$ ) plastic liners filled with soilless potting mix (ProMix BX; Premier Hort Tech, Quakertown, PA) and fertilized 3 weeks later with $40 \mathrm{ml}$ of Peter's soluble 20-10-20 (N-P-K) fertilizer (R. J. Peters 
Inc., Allentown, PA). When plants reached the three- to four-leaf stage, medium size plants were selected and polyvinylidene chloride film (Saran Wrap) was securely fitted around the stem to cover the soil and prevent soil exposure from the NP spray. Healthy 3-to 4-week-old seedlings (10 replicates) were sprayed with NP suspensions of $\mathrm{CuO}$ $(30 \mathrm{~nm}), \mathrm{MnO}(40 \mathrm{~nm}), \mathrm{SiO}(20$ to $30 \mathrm{~nm}), \mathrm{TiO}_{2}(30 \mathrm{~nm}$, rutile), and $\mathrm{ZnO}(10$ to $30 \mathrm{~nm}$ ) (US Research Nanomaterials, Houston, TX) at $1,000 \mu \mathrm{g} / \mathrm{ml}$. NP suspensions were sonicated for at least $10 \mathrm{~min}$ in an FS20H Ultrasonic cleaner (Fisher Scientific Inc., Pittsburgh) prior to application; a stable dispersion was evident in each case. Plants were sprayed using plastic spray atomizers until leaves were wet (1 to $2 \mathrm{ml}$ per plant) and allowed to dry, and the film was removed. Plants were subirrigated to avoid wetting the leaves. Control plants were sprayed with sonicated distilled water. Greenhouse temperatures averaged 17 to $22^{\circ} \mathrm{C}$ at night and 19 to $25^{\circ} \mathrm{C}$ during the day.

One week later, 10 treated seedlings were then transplanted into $10-\mathrm{cm}$ pots filled with noninfested potting mix (1 plant/pot). An additional 10 replicates of each treatment were transplanted into pots filled with potting mix infested with dried ground millet that had been colonized by inoculum $F$. oxysporum f. sp. niveum (1 plant/pot). Inoculum was prepared on Japanese millet autoclaved with distilled water $(1: 1, w t / w t)$ for $1 \mathrm{~h}$ on two consecutive days, then seeded with three agar plugs colonized by an $F$. oxysporum f. sp. niveum isolate and allowed to grow for 2 weeks at 22 to $25^{\circ} \mathrm{C}$. Millet was air dried, ground in a mill, and passed through a 0.5 -mm sieve. The millet inoculum was incorporated into potting mix at $1 \mathrm{~g}$ of inoculum per liter of potting mix. The isolate of $F$. oxysporum f. sp. niveum was isolated from infested watermelon seed; its race was not determined. One week later, $1 \mathrm{~g}$ of infested potting mix and noninfested potting mix from greenhouse pots was serially diluted onto Komada's selected agar (Komada 1975); the inoculum stock was found to contain $F$. oxysporum at approximately $1 \times 10^{5} \mathrm{CFU} / \mathrm{g}$ of potting mix, whereas noninfested soil contained $F$. oxysporum at $0.9 \times 10^{2}$ $\mathrm{CFU} / \mathrm{g}$ of potting mix, producing an inoculum load of $9.9 \times 10^{4} \mathrm{CFU} / \mathrm{g}$ of soil. No effort was made at this time to distinguish $F$. oxysporum from the morphologically identical $F$. oxysporum $\mathrm{f}$. sp. niveum.

The pots were placed on greenhouse benches in a two-by-five (infestation by NP treatment, respectively) randomized complete block design with 10 replicates/treatment. Each pot received $50 \mathrm{ml}$ of a complete fertilizer solution (20-20-20, N-P-K) once per month. As symptoms of disease developed, plants were rated for severity approximately twice per week, for a total of seven times, on a scale of 1 to 5 , where $1=$ no disease, $2=$ slightly stunted, $3=$ stunted or partially wilted, $4=$ completely wilted, and $5=$ dead. The disease ratings were rank transformed as discussed below. The pathogen was reisolated from wilted stem tissue to confirm its association with the disease. No Fusarium spp. were isolated from healthy stems. After 5 weeks, the experiment was terminated and the plant tops and roots were weighed for fresh and dry weights. Root tissue was later ground for elemental analysis, as described below.

Greenhouse experiment 2 was a repeat of experiment 1 but differed from the first experiment in that five additional treatments were added. The larger bulk equivalents of $\mathrm{CuO}, \mathrm{MnO}, \mathrm{SiO}, \mathrm{TiO}_{2}$, and $\mathrm{ZnO}$ (Fisher Scientific, Pittsburgh, PA) were compared with the NP forms used in experiment 1 to assess the effect of NP size on growth and disease. In addition, NP suspensions were sonicated using a probe sonicator (FB505; Fisher Scientific) at 50\% amplitude for $2 \mathrm{~min}$ to aid in dispersing particles prior to treatment. On 10 April, seed were germinated in 36-cell liners (1 plant/cell) filled with potting mix and fertilized 3 weeks later with $40 \mathrm{ml}$ of Peter's soluble 20-10-20 (N-P-K) fertilizer. Plants were treated with NP or bulk equivalents $(1,000 \mu \mathrm{g} / \mathrm{ml})$ on 8 May. Therefore, a 2-by-10 (infestation by NP or bulk treatments, respectively) factorial randomized complete block design, with 10 replicate plants/treatment, was used. Growth conditions in the greenhouse were warmer $\left(17\right.$ to $22^{\circ} \mathrm{C}$ at night and 20 to $27^{\circ} \mathrm{C}$ during the day) for greenhouse experiment 2 than those in first experiment; therefore, experiment 2 was terminated after 5 weeks because the disease appeared sooner. Plants were rated five times beginning 3 weeks after transplanting, and the rank sum transformation was calculated as discussed below. At the end of the experiment, plants were harvested for fresh and dry weights; the dry root tissue was digested for elemental analysis, as described below.
Greenhouse experiment 3 was established to assess the effect of increasing rates of $\mathrm{CuO} \mathrm{NP}$ on watermelon growth and Fusarium wilt. The experiment was conducted three times with five, six, and eight replicates, respectively. Seed were germinated on 5 November, 16 June, and 21 August. Healthy 3- to 4-week-old seedlings were sprayed with $\mathrm{CuO} \mathrm{NP}$ at $0,250,500$, and $1,000 \mu \mathrm{g} / \mathrm{ml}$, prepared as described above. Plants were transplanted into soil infested with $F$. oxysporum $\mathrm{f}$. sp. niveum or into noninfested soil and rated once after 5 weeks, as described above. Fresh and dry weights were determined.

Field experiments. Field experiment 1 examined the effect of foliar sprays of $\mathrm{NP}$ of $\mathrm{B}, \mathrm{CuO}, \mathrm{MnO}$, and $\mathrm{ZnO}$ on watermelon yield and Fusarium wilt when compared with an untreated control. Fertilizer (10-10-10, N-P-K) was broadcast over 0.9 -m-wide rows at $112 \mathrm{~kg} / \mathrm{ha}$. The rows were set $6 \mathrm{~m}$ apart, covered in black plastic mulch, and lined with irrigation drip tape. Rows were partitioned into 30 microplots $\left(5.6 \mathrm{~m}^{2}\right)$. Seed were germinated on 26 May in 36-cell liners ( 1 plant/cell) filled with potting mix and fertilized 3 weeks later with $40 \mathrm{ml}$ of Peter's soluble 20-10-20 (N-P-K) fertilizer. Four-week-old transplants were sprayed on 23 June in the greenhouse with 1 to $2 \mathrm{ml}$ of one of five treatments ( $\mathrm{NP}$ of $\mathrm{B}$ [2 $\mathrm{nm}$ ], $\mathrm{CuO}, \mathrm{MnO}$, or $\mathrm{ZnO}$ applied at $500 \mu \mathrm{g} / \mathrm{ml}$ ) or with 1 to $2 \mathrm{ml}$ of distilled water for the untreated control. Metalloid NP of B were included in this experiment because soil tests at this site indicated very low to no B in the soil and it was of interest to know if foliar sprays could benefit growth or disease suppression. One week later (1 July), two transplants were set $30 \mathrm{~cm}$ apart in the center of each microplot. There were six replicate microplots/treatment. Planting holes were each infested with approximately $2 \mathrm{~g}$ of millet inoculum and hand mixed into the soil immediately before transplanting. In addition, another 30 microplots were planted and prepared the same way but were not infested with the millet inoculum. Plants were sprayed again on 7 July with 1 to $2 \mathrm{ml}$ of NP solutions 1 week after planting. Effort was made to direct the spray onto foliage and minimize any contact with the black plastic or soil. Plants were rated for disease three times (on 7 July, 21 July, and 5 August) using the same scale described above. The experiment was conducted only once in Griswold, CT.

Field experiment 2 was designed to compare $\mathrm{CuO} \mathrm{NP}$ to the bulk form of $\mathrm{CuO}$ along with two commercial $\mathrm{Cu}$ fungicides-Kocide 2000 (Certis USA, Columbia, MD) and Cu octanoate soap (Bonide Product Inc., Oriskany, NY) - for their effect on yield and Fusarium wilt of watermelon. Seed were germinated on 26 May in 36-cell liners (1 plant/cell) filled with potting mix and fertilized 3 weeks later with $40 \mathrm{ml}$ of Peter's soluble 20-10-20 (N-P-K) fertilizer. Four weeks later (17 June), healthy plants were sprayed with one of five treatments. Because the $\mathrm{CuO} N \mathrm{NP}$ treatment $(500 \mu \mathrm{g} / \mathrm{ml})$ provides elemental $\mathrm{Cu}$ at $400 \mu \mathrm{g} / \mathrm{ml}$, the amount of product in the other treatments was adjusted to deliver the same amount $(400 \mu \mathrm{g} / \mathrm{ml})$ of elemental $\mathrm{Cu}$. Five treatments were applied: no treatment (control), $\mathrm{CuO} \mathrm{NP}$ at $500 \mu \mathrm{g} / \mathrm{ml}$, a corresponding bulk equivalent form of $\mathrm{CuO}(500 \mu \mathrm{g} / \mathrm{ml})$, Kocide $2000(1,142 \mu \mathrm{g} / \mathrm{ml}, 35 \%$ metallic $\mathrm{Cu})$, and $\mathrm{Cu}$ octanoate soap $(0.22 \mathrm{ml} / \mathrm{ml}, 1.8 \%$ metallic $\mathrm{Cu})$.

The experimental plots were prepared in Hamden, CT on a Cheshire fine sandy loam (Typic Dystrocrept, $\mathrm{pH}$ 6.1). The field was prepared by broadcasting 10-10-10 (N-P-K) fertilizer at $112 \mathrm{~kg} / \mathrm{ha}$ and rototilling. Raised beds were prepared under 4-mil black plastic along with drip irrigation tape (Berry Plastics Holding Corp., Evansville, IN). Root systems of treated transplants were removed from plastic cell linings and dipped in spore suspensions of $F$. oxysporum f. sp. niveum before planting on 23 May. Inoculum was increased on $25 \%$ potato dextrose agar by seedling cultures for 2.5 weeks at 23 to $28^{\circ} \mathrm{C}$, rinsing the spores and mycelium off with distilled water, and adjusting to $5 \times 10^{4}$ conidia/ml with a hemocytometer. A one-way randomized blocked design with six replicates was used. After harvest, the field was planted with winter rye, and plowed again in May 2016. The experiment was repeated in 2016. Seed were germinated on 1 June, treated on 23 June, and planted on 30 June. Plots were artificially infested with $2 \mathrm{~g}$ of millet inoculum, which was hand mixed into the soil before planting. Plots were randomly reassigned to the different treatments and planted on 23 June. Disease ratings were conducted three times in 2015 (on 29 July and 15 and $30 \mathrm{Au}$ gust) and three times in 2016 (on 3, 16, and 31 August). 
Elemental analysis. Root tissues from greenhouse experiment 1 and 2 and fruit tissues from field experiments 1 (2015) and 2 (2015 and 2016) were assayed for $\mathrm{Cu}$ levels. The edible fruit tissue (minus seeds) was sampled from one medium size fruit from each plot in late August. Tissue was dried in an oven at $50^{\circ} \mathrm{C}$, ground in a Wiley mill, and passed through a 1-mm sieve. Digests on ground samples $(0.5 \mathrm{~g})$ were done in $50-\mathrm{ml}$ polypropylene digestion tubes with $5 \mathrm{ml}$ of concentrated nitric acid at $115^{\circ} \mathrm{C}$ for 45 min using a hot block (DigiPREP System; SCP Science, Champlain, NY). The Ca, Cu, $\mathrm{Fe}, \mathrm{K}, \mathrm{Mg}, \mathrm{Mn}, \mathrm{P}, \mathrm{S}$, and $\mathrm{Zn}$ content was quantified using inductively coupled plasma optical-emission spectroscopy (ICP-OES) on an iCAP 6500 (Thermo Fisher Scientific, Waltham, MA), and element content was expressed as micrograms per gram (dry weight) of plant tissue.

Gene-expression analysis. For transcriptomic analysis, two separate greenhouse experiments were performed on watermelon transplants. On 25 August, seed were germinated in 36-cell liners (1 plant/cell) filled with potting mix and fertilized 3 weeks later with $40 \mathrm{ml}$ of Peter's soluble 20-10-20 (N-P-K) fertilizer. Plants were treated on 25 September with 1 to $2 \mathrm{ml}$ of $\mathrm{CuO} \mathrm{NP}(500 \mu \mathrm{g} / \mathrm{ml})$ or with distilled water and then grown for 3 weeks in soil infested with millet inoculum of $F$. oxysporum f. sp. niveum or in noninfested potting mix. Symptoms became evident in the inoculated controls 3 weeks after planting. Plants were then harvested and roots were washed clean of soil and stored at $-80^{\circ} \mathrm{C}$. Roots were bulked and total RNA from $0.1 \mathrm{~g}$ of fresh roots was extracted using a Sigma-Aldrich Spectrum Plant Total RNA Kit (Sigma-Aldrich, St. Louis). Total RNA sample quality and quantity was assessed by a Thermo Scientific Nanodrop Lite Spectrophotometer (Thermo Fisher Scientific, Wilmington, DE) and gel electrophoresis. Two-step reverse transcription was performed on $1 \mu \mathrm{g}$ of the total RNA extracted using the Qiagen QuantiTect Reverse Transcription kit (Qiagen, Velno, The Netherlands). Reverse-transcription real-time polymerase chain reaction (RT-qPCR) was carried out using the Bio-Rad SsoAdvanced Universal SYBR Green Supermix (Bio-Rad, Hercules, CA) in an optical 96-well plate with the Bio-Rad CFX96 Touch Real-Time PCR Detection System (Bio-Rad). Based on previous work with Arabidopsis thaliana, ortholog gene coding sequences were obtained through the BLAST tool of Cucurbigene database resource (https://cucurbigene.upv.es/) for $C$. lanatus (Pagano et al. 2016). A 1·e-20 (E-value) threshold with the query sequence of $A$. thaliana was used to identify the orthologous coding sequences in watermelon; in total, nine orthologs were identified in both of the species (Table 1). Specific primers for each selected gene transcript were designed using the Primer3 software (http://primer3.ut.ee/); the thermal profile for RT-qPCR amplifications was $95^{\circ} \mathrm{C}$ for $10 \mathrm{~min}$, $95^{\circ} \mathrm{C}$ for $15 \mathrm{~s}$, and $60^{\circ} \mathrm{C}$ for $60 \mathrm{~s}$ for 40 cycles. Confirmation of the single amplicon in each reaction was performed by a dissociation-curve step. Relative expression was estimated through the $\Delta \Delta \mathrm{Ct}$ method using $\beta$-actin of $C$. lanatus as the housekeeping gene. Gene expression was expressed relative to control plants that were not inoculated or treated with $F$. oxysporum f. sp. niveum.

PPO and protein analysis. For enzyme activity analysis, watermelon that had been sprayed in the greenhouse with 1 to $2 \mathrm{ml}$ of $\mathrm{CuO} \mathrm{NP}, \mathrm{MnO}$, and $\mathrm{ZnO}$ at $500 \mu \mathrm{g} / \mathrm{ml}$ were grown in soil infested

Table 1. Nine orthologs from Arabidopsis thaliana also found in Citrullus lanatus var. lanatus

\begin{tabular}{|c|c|c|}
\hline Reference $^{\mathrm{z}}$ & Gene ID C. lanatus & Gene function \\
\hline $\mathrm{CCH}$ & Cla020497 & Copper chaperone, cch \\
\hline COX11 & $\mathrm{Cla} 002392$ & $\begin{array}{l}\text { Cytochrome c oxidase assembly } \\
\text { protein ctag/Cox } 11 \text { family }\end{array}$ \\
\hline HMA1 & Cla006819 & Heavy metal atpase 1, hmal \\
\hline HMA5 & Cla011458 & Heavy metal atpase 5 , hma5 \\
\hline RAN1 & Cla009875 & Heavy metal atpase 7, hma7, ran1 \\
\hline CSD1 & Cla011299 & $\begin{array}{l}\text { Copper/zinc superoxide dismutase } 1 \text {, } \\
\text { csd1, sod } 1\end{array}$ \\
\hline PAO & Cla015262 & Polyamine oxidase 1 , pao1 \\
\hline $\mathrm{PPO}$ & Cla019486 & Polyphenol oxidase chloroplastic-like \\
\hline PR1 & Cla001623 & Pathogenesis-related gene 1 \\
\hline
\end{tabular}

${ }^{\mathrm{z}}$ BLAST tool of Cucurbigene database resource for $C$. lanatus. with $F$. oxysporum f. sp. niveum in the greenhouse, along with an untreated control and noninoculated untreated control. Plants were harvested 6 weeks later. Roots were frozen at $-80^{\circ} \mathrm{C}$. Frozen roots were ground in liquid nitrogen using a mortar and pestle, and a $10 \%$ homogenate was prepared in $50 \mathrm{mM}$ potassium phosphate buffer $(\mathrm{pH}$ 7.4) containing $1 \mathrm{mM}$ EDTA, $1 \%$ (wt/vol) polyvinyl-pyrrolidone, and $0.5 \%$ Triton $\mathrm{X}-100$ at $4^{\circ} \mathrm{C}$. The samples were centrifuged at $10,000 \times g$ for $20 \mathrm{~min}$ at $4^{\circ} \mathrm{C}$, and the supernatant was collected and stored at $-80^{\circ} \mathrm{C}$. PPO activity was measured in a 96-well microplate reader, each well containing $150 \mu \mathrm{l}$ of $50 \mathrm{mM}$ catechol as substrate and $50 \mu \mathrm{l}$ of enzyme extract; each sample was repeated twice in different wells. The absorbance of the reaction mixture was measured at a wavelength of $490 \mathrm{~nm}$ at ambient temperature using SpectraMax M5 (PN 0112-0115; Molecular Devices Corp., Sunnyvale, CA) at $0 \mathrm{~min}$ and after $60 \mathrm{~min}$ of incubation at $37^{\circ} \mathrm{C}$. The PPO activity was expressed as units per minute (per milligram of protein) (Soffan et al. 2014). The total soluble protein content in the tissues was examined according to Bradford using a bovine serum albumin standard (Bradford 1976).

Statistical analyses. Data for fresh weight and yield from experimental repetitions in the greenhouse and field were analyzed using the SYSTAT V.10 (Cranes Software International Limited, Bangalore, Karnataka, India) procedure for mixed-model analysis of variance (ANOVA), with year (or experimental repetition) and replication as random effects and NP treatments and inoculations as main effects. Field data from plots with NP treatments in artificially infested plots or in noninfested plots were analyzed separately as one-way ANOVA. Data from greenhouse experiment 3 and field experiment 2 sets were combined when experimental repetition-treatment interactions were not significant. Yield data (in kilograms) were transformed to square root of yield when it was necessary to satisfy requirements for homogeneity of variance. Means were separated using Tukey's honesty significant difference test at $P<0.05$. Because disease severity values were categorical and ordinal, they were subjected to a rank transformation where disease ratings were totaled over the course of the experiment and analyzed using the nonparametric Wilcoxon Signed Fisher's test at $P=0.05$ (Conover and Iman 1981).

\section{Results}

Greenhouse experiments. Watermelon plants typically showed wilt symptoms 14 to 21 days after inoculation. Discolored stem tissue consistently gave rise to $F$. oxysporum when placed on selective agar (Komada 1975) where the fungus was absent from healthy stems.

In greenhouse experiment 1 , fresh weights were harvested after 5 weeks. Plants treated with $\mathrm{CuO}$ NP were significantly (21\%) larger than the untreated plants and were approximately $33 \%$ larger than plants amended with $\mathrm{NP} \mathrm{MnO}, \mathrm{SiO}, \mathrm{TiO}_{2}$, or $\mathrm{ZnO}$ (Fig. 1). Seven disease ratings were rank transformed and analyzed by a Wilcoxon



Fig. 1. Effect of foliar applications of nanoparticles of metal oxides on fresh weights and the rank sums of disease ratings of watermelon plants grown in soil infested with Fusarium oxysporum f. sp. niveum in greenhouse experiment 1. Plant weight data designated with differing letters $(\mathrm{x}$ and $\mathrm{y})$ are significantly different according to Tukey's honestly significant difference test at $P=0.05$. Rank sums of disease ratings $(n=10)$ represent sums of seven disease ratings (1-to-5 scale) taken over 16 days; values with differing letters $(a$ and $b)$ are significantly different according to the Wilcoxon Signed-Rank test $(P=0.05)$. 
Rank-Signed test. Plants treated with $\mathrm{CuO} \mathrm{NP}$, and $\mathrm{ZnO}$ had rank sums of disease rating values that were significantly less than untreated controls (Fig. 1). Root $\mathrm{Cu}$ levels from $\mathrm{CuO} \mathrm{NP}$ treatment $(\mathrm{Cu}$ at $44.0 \mu \mathrm{g} / \mathrm{g}$ of root) was $31 \%$ more than the untreated control roots $(\mathrm{Cu}$ at $30.5 \mu \mathrm{g} / \mathrm{g}$ of root $)(P=0.012)$. No difference in root $\mathrm{Zn}$ levels was observed between the control ( $\mathrm{Zn}$ at $203.6 \mu \mathrm{g} / \mathrm{g}$ of root) and the NP $\mathrm{ZnO}$ treatment (198.7 $\mu \mathrm{g} / \mathrm{g}$ of root). Roots from the other treatments were not assayed in this experiment because they had no marked effect on growth or disease.

In the repetition (greenhouse experiment 2), $\mathrm{CuO} \mathrm{NP}, \mathrm{MnO}, \mathrm{SiO}$, $\mathrm{TiO}_{2}$, or $\mathrm{ZnO}$ were again examined along with five additional treatments of the bulk forms of the metal oxides on watermelon plants in soil infested with $F$. oxysporum $\mathrm{f}$. sp. niveum. Neither the NP nor the bulk forms of the metal oxides affected plant fresh weights when compared with untreated controls but the $\mathrm{CuO}$ NP treatment produced the largest fresh weights, which were significantly larger than the bulk form of $\mathrm{CuO}(P=0.048)$ and $\mathrm{TiO}(P=0.035)$ and the NP forms of $\mathrm{MnO}(P=0.035)$, $\mathrm{TiO}(P=0.035)$, and $\mathrm{ZnO}(P=0.038)$ (Fig. 2). Symptoms of disease appeared after 2 weeks. Five disease evaluations were then made over a 3 -week period and rank transformed. Compared with the control, none of the bulk metal oxides were effective in reducing disease (Fig. 3). However, $\mathrm{CuO}$ NP significantly reduced the rank sum of disease ratings by approximately $35 \%$ compared with the untreated control $(P=0.012)$. When aciddigested root tissues from plants were assayed by ICP-OES for element content, a $133 \%$ increase in Cu levels was observed in plants



Fig. 2. Effect of foliarly sprayed nanoparticles (NP) of metallic oxides and their larger bulked oxide equivalents on fresh weights of watermelon grown in soil infested with Fusarium oxysporum f. sp. niveum in greenhouse experiment 2. Plant weight data designated with differing letters are significantly different according to Tukey's honestly significant difference test at $P=0.05$.

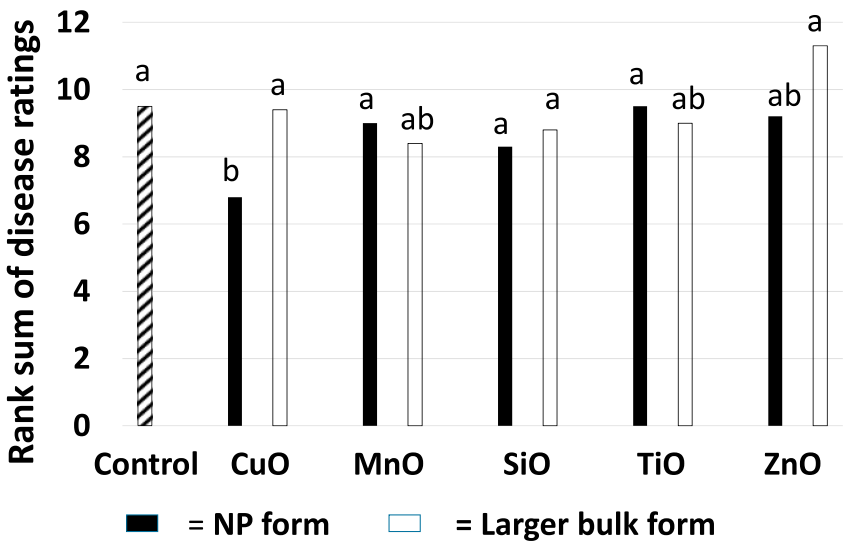

Fig. 3. Effect of foliarly sprayed nanoparticles (NP) of metal oxides and the larger bulk oxide equivalents on rank sums of disease ratings of watermelon plants grown in soil infested with Fusarium oxysporum f. sp. niveum in greenhouse experiment 2. Values $(n=10)$ represent the rank sums of five disease ratings (1-to-5 scale) taken over 19 days; values with differing letters are significantly different according to the Wilcoxon Signed-Rank test $(P=0.05)$. treated with $\mathrm{CuO} \mathrm{NP}$ when compared with untreated controls; notably, $\mathrm{Cu}$ content in the NP treatment was double that in roots treated with corresponding bulk $\mathrm{CuO}$ (Fig. 4). Root levels of other treatment elements did not statistically differ from controls (data not shown).

Given that $\mathrm{CuO}$ NP perform better that other metallic oxides, greenhouse experiment 3 was conducted three times to examined the effect of increasing $\mathrm{CuO}$ rates on plant growth and disease severity (Fig. 5). CuO NP applied at 500 and $1,000 \mu \mathrm{g} / \mathrm{ml}$ increased plant growth in infested potting soil but only the $500-\mu \mathrm{g}$ rate increased growth in noninfested potting soil. Similarly, the final disease ratings were lowest at 250 and $500 \mu \mathrm{g} / \mathrm{ml}$ when compared with controls; the highest rate was statistically insignificant (Fig. 6). Given these results, subsequent studies used $500 \mu \mathrm{g} / \mathrm{ml}$ as the chosen application rate. Assuming 1 to $2 \mathrm{ml}$ was being sprayed per plant, we estimate that only 0.5 to $1.0 \mathrm{mg}$ of $\mathrm{CuO}(0.4$ to $0.8 \mathrm{mg}$ of metallic $\mathrm{Cu})$ was being applied per plant.

Field plot experiments. Field experiment 1 was designed to test the effect of $\mathrm{B}, \mathrm{CuO}, \mathrm{MnO}$, and $\mathrm{ZnO} \mathrm{NP}$ on yield and disease of watermelon grown in soil infested with $F$. oxysporum $\mathrm{f}$. sp. niveum or left noninfested. Plots that were artificially infested had $19 \%$ less yield than healthy control plots. The total yield among the infested plots was highest for plants treated with $\mathrm{CuO}$ NP; yields were increased by $35 \%$ relative to untreated controls (Fig. 7). Disease appeared in infested plots approximately 3 weeks after transplanting. Plots treated with $\mathrm{NP}$ of $\mathrm{B}, \mathrm{MnO}$, and $\mathrm{ZnO}$ did not differ from the untreated control or plots treated with $\mathrm{CuO}$. All NP treatments $(\mathrm{B}, \mathrm{CuO}$,

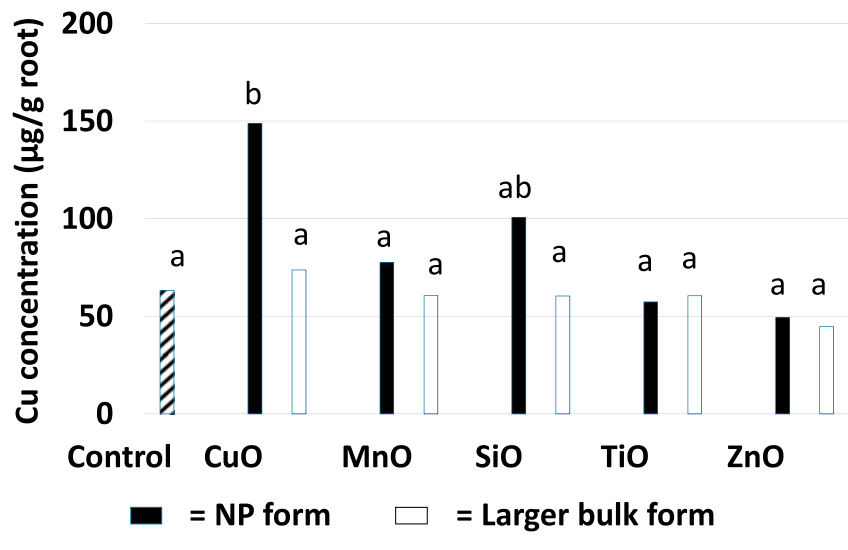

Fig. 4. Effect of foliarly sprayed nanoparticles (NP) of metal oxides and the larger bulk oxide equivalents on the concentration of $\mathrm{Cu}$ in roots of watermelon grown in soil in greenhouse experiment 2. Mean Cu concentrations designated with differing letters are significantly different according to Tukey's honestly significant difference test at $P=0.05$.

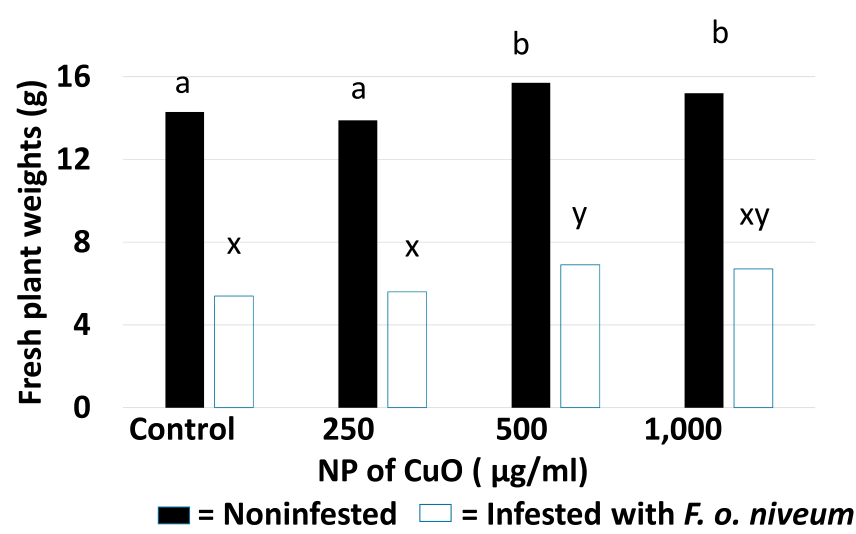

Fig. 5. Effect of the rate of foliarly sprayed nanoparticles (NP) of $\mathrm{CuO}$ on fresh weights of watermelon grown in soil infested with Fusarium oxysporum f. $\mathrm{sp}$. niveum or in noninfested soil in greenhouse experiment 3 ; means designated with differing letters (noninfested refers to letters $a$ and $b$ ) or (infested refers to letters $x$ and y) are significantly different according to Tukey's honestly significant difference test at $P=0.05$. 
$\mathrm{MnO}$, and $\mathrm{ZnO}$ ) significantly reduced the rank sum of the disease ratings relative to the control but plants treated with $\mathrm{CuO}$ NP had rank sums significantly lower than the other NP treatments (Fig. 8). No disease appeared on plants grown in noninfested soil. Fruit number was not affected, indicating that fruit size was being affected by the treatments (data not shown). Compared with untreated controls, the NP treatments had no effect on the edible fruit concentration of B (range 3.5 to $31.6 \mu \mathrm{g} / \mathrm{g}$, mean $17.0 \mu \mathrm{g} / \mathrm{g}$ ), Cu (range 1.3 to $5.8 \mu \mathrm{g} / \mathrm{g}$, mean $3.7 \mu \mathrm{g} / \mathrm{g}$ ), Mn (range 1.7 to $8.7 \mu \mathrm{g} / \mathrm{g}$ mean, $4.4 \mu \mathrm{g} / \mathrm{g}$ ), or $\mathrm{Zn}$ (range 5.9 to $17.5 \mu \mathrm{g} / \mathrm{g}$, mean $10.5 \mu \mathrm{g} / \mathrm{g}$ ). In addition, fruit concentrations of $\mathrm{Ca}, \mathrm{Fe}, \mathrm{K}, \mathrm{Mg}, \mathrm{Mo}, \mathrm{Na}, \mathrm{P}$, or S were unaffected by the NP treatments (data not shown).

Field experiment 2 was designed to compare $\mathrm{CuO}$ NP with the corresponding bulk equivalent forms of $\mathrm{CuO}$, along with a conventional $\mathrm{Cu}$ hydroxide fungicide (Kocide 2000) and an organic $\mathrm{Cu}$ fungicide soap (Cu octanoate). In 2015, all transplants were inoculated with a root drench of conidia of $F$. oxysporum $\mathrm{f}$. sp. niveum, and disease severity was extremely low. In 2016, transplants were planted into soil infested with millet inoculum and the disease severity was more evident, and appeared 4 weeks after planting. Although the plants in 2016 that were treated with $\mathrm{CuO}$ NP had rank sums of disease ratings $25 \%$ lower than the control, these values were not significantly different from other treatments (data not shown). The yield was significantly lower in 2016 than in $2015(P<0.001)$. The average yield per plot in 2015 was $45.1 \mathrm{~kg}$ whereas, in 2016 , yields averaged $16.0 \mathrm{~kg}$. Even though the years differed, there were no significant interactions observed in the yield data between the years and the treatments $(P=$ $0.97)$; as such, the five treatments for both data sets were combined

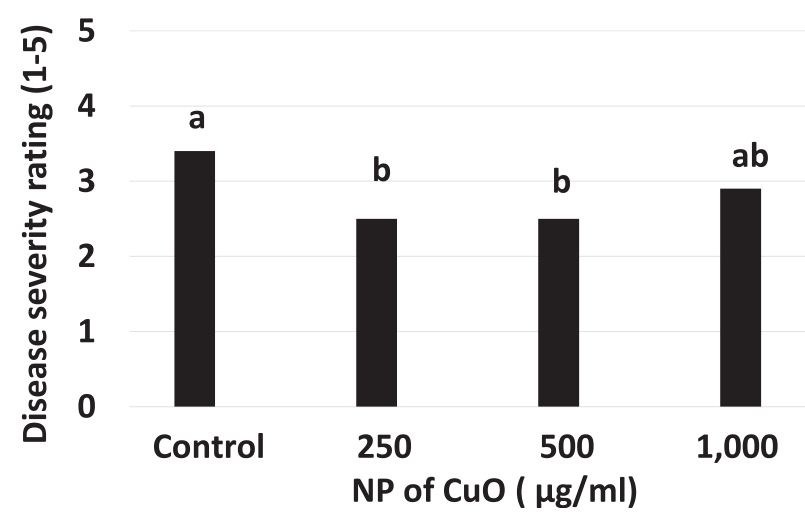

Fig. 6. Effect of the rate of foliarly sprayed nanoparticles (NP) of $\mathrm{CuO}$ on the final disease severity rating (1 to 5 ) of watermelon grown in soil infested with Fusarium oxysporum f. sp. niveum in greenhouse experiment 3. Values represent mean disease severity ratings from three trials $(n=19)$; values with differing letters are significantly different according to the Wilcoxon Signed-Rank test $(P=0.05)$.

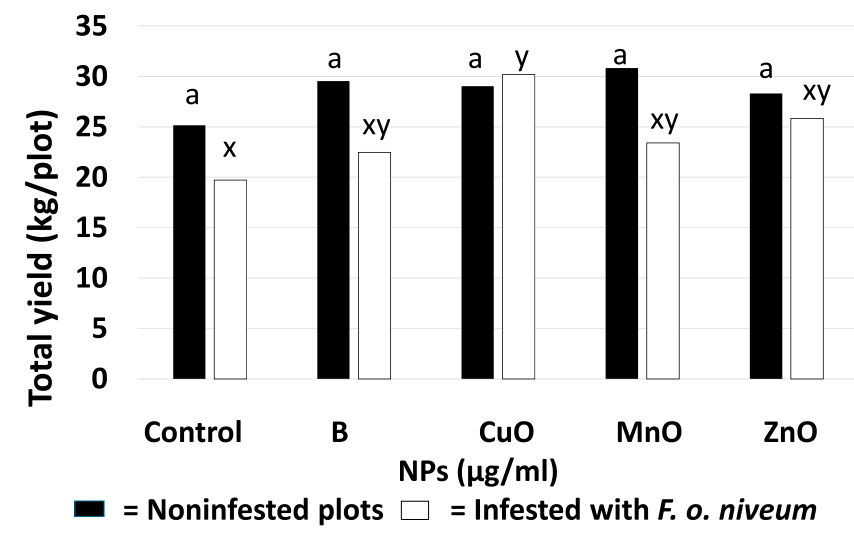

Fig. 7. Mean watermelon yield from plants treated with foliarly sprayed nanoparticles (NP) of $\mathrm{B}, \mathrm{CuO}, \mathrm{MnO}$, or $\mathrm{ZnO}$ in noninfested soil or in soils artificially infested with Fusarium oxysporum f. sp. niveum in field experiment 1. Differing letters represent significant differences by Tukey honestly significant difference test. and analyzed for yield using the square root transformation (Fig. 9). The combined data revealed the yield (in kilograms) was highest in plants treated with $\mathrm{CuO} \mathrm{NP}$ and was the lowest in the untreated control plots $(P=0.020)$. CuO NP treatment resulted in an average $53 \%$ increase in yield over the untreated control. Other than $\mathrm{CuO} N \mathrm{~N}$, no other treatments resulted in statistically significant differences from the untreated control or from each other. Acid digests of watermelon flesh were analyzed by ICP-OES in each year and no significant differences were found in the $\mathrm{Cu}$ levels present in the fruit across all treatments (Fig. 10).

Gene expression and protein analysis. Gene-expression analysis was conducted to identify up- and downregulated genes for plants treated with $\mathrm{CuO} \mathrm{NP}$ and $F$. oxysporum f. sp. niveum. Plants were harvested in two experiments for fresh weights when symptoms became evident in plants grown in infested soils. Healthy plants exposed to $\mathrm{CuO} \mathrm{NP}$ were $26 \%$ larger in fresh weight while inoculated plants were $21 \%$ larger when they were treated with $\mathrm{CuO}$ NP (Table 2). In this experiment, inoculation did not significantly reduce plants weights. Root digests revealed a significant reduction in $\mathrm{Cu}$ following inoculation with $F$. oxysporum $\mathrm{f}$. sp. niveum.

The genes of interest, along with their ID number from the $C$. lantus gene bank, are presented in Table 1. Genetic analyses performed with RT-qPCR are expressed relative to the untreated noninoculated control (Fig. 11). Of the nine genes examined, three (PPO, pathogenicityrelated $[\mathrm{PR}] 1$, and polyamine oxidase [PAO]) showed significant upregulation. In both repetitions of the experiment, PPO expression was strongly upregulated when $\mathrm{CuO} \mathrm{NP}$ was combined with $F$. oxysporum $\mathrm{f}$. sp. niveum inoculation (experiment $1=9$ times higher and experiment $2=29$ times higher) compared with the untreated healthy control. Gene expression was unchanged in other treatments. The



Fig. 8. Means of rank sums of three disease ratings (1-to- 5 scale) taken over 30 days of watermelon plants grown in experimental field plots in soil infested with Fusarium oxysporum f. sp. niveum and treated with nanoparticles of $\mathrm{B}, \mathrm{CuO}, \mathrm{MnO}$, or $\mathrm{ZnO}$ in field experiment 1 . Values with differing letters are significantly different according to the Wilcoxon Signed-Rank test $(P=0.05)$.

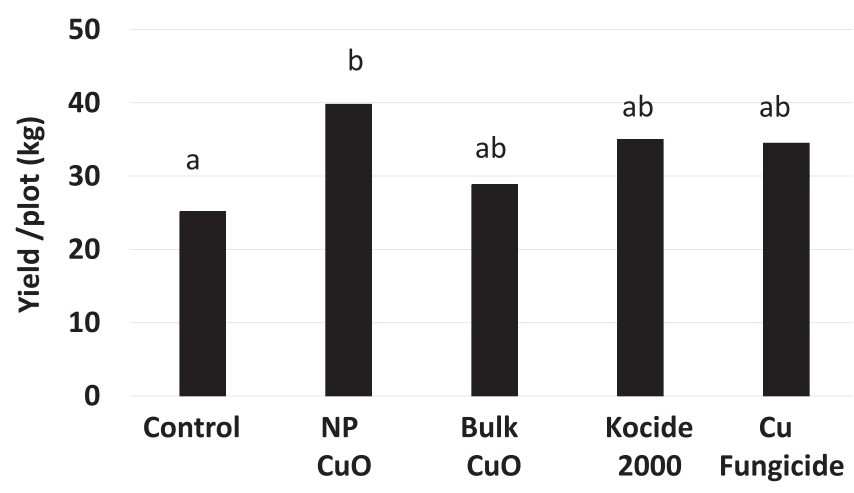

Fig. 9. Mean watermelon yield from plants treated with foliarly sprayed $\mathrm{CuO}$ nanoparticles (NP), the larger bulk oxide equivalent, or Cu fungicides (Kocide 2000 or Cu octanoate soap) in Hamden, CT in field experiment 2. Mean yield values designated with differing letters are significantly different according to Tukey's honestly significant difference test at $P=0.05$. 
root expression of the gene encoding PR1 protein was also upregulated compared with the untreated healthy control (experiment $1=$ 6 times higher and experiment $2=119$ times higher) in plants treated with both the $\mathrm{CuO} \mathrm{NP}$ and the pathogen. The expression of the PR1 gene was also increased in plants treated with $\mathrm{CuO} \mathrm{NP}$ alone but not in plants inoculated with $F$. oxysporum $\mathrm{f}$. sp. niveum alone. PAO1 activity was only increased in one of the experimental repetitions. Across all genes and treatments, the greatest upregulation was consistently observed upon treatment with both $\mathrm{CuO} \mathrm{NP}$ and $F$. oxysporum f. sp. niveum. PPO activity in the roots of watermelon treated with $\mathrm{CuO} \mathrm{NP}$ and $F$. oxysporum $f$. sp. niveum increased with $\mathrm{CuO}$ and pathogen exposure, although the effects were statistically insignificant (Fig. 12). PPO activity was unaffected by $\mathrm{NP}$ of $\mathrm{MnO}$ or $\mathrm{ZnO}$. Similarly, total protein amount was not significantly affected by treatment.

\section{Discussion}

The ability of metal oxide NP via foliar application to affect disease resistance is a relatively new and unexplored concept. Most studies on NP in plant pathology have examined direct antifungal activity against the pathogen of concern (Dimkpa et al. 2013b; Jo et al. 2009; Kanhed et al. 2014; Kim et al. 2008, 2009; Ocsoy et al. 2013; Saharan et al. 2015; Strayer-Scherer et al. 2018; Wani and Shah 2012; Zabrieske et al. 2015). The current study showed that foliar application of NP of the metalloid B and the metal oxides could positively affect growth and inhibit disease development, presumably through enhanced mineral nutrition and host defense. Although NP performance varied across our studies, we observed that $\mathrm{CuO} \mathrm{NP}$ were more consistently associated with increases in growth and yield of plants, regardless of disease status. Our findings are in agreement

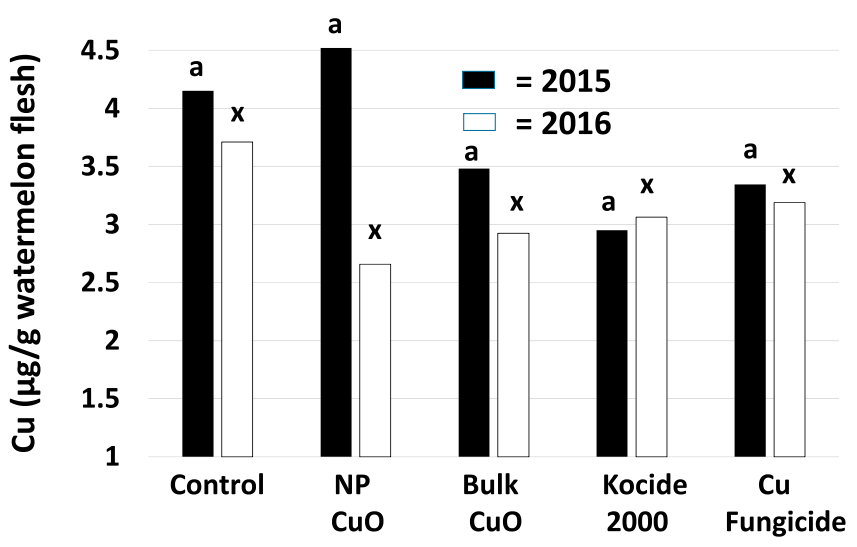

Fig. 10. Mean $\mathrm{Cu}$ concentrations in edible fruit of watermelon treated with foliarly sprayed $\mathrm{CuO}$ nanoparticles (NP), the larger bulk oxide equivalent, or $\mathrm{Cu}$ fungicides (Kocide 2000 or Cu octanoate soap) in Hamden, CT in field experiment 2. Cu concentrations were not significantly different according to Tukey's honestly significant difference test at $P=0.05$ in either year (letters a and $\mathrm{x}$ refer to 2015 and 2016, respectively).

Table 2. Effect of nanoparticles (NP) of $\mathrm{CuO}$ and Fusarium oxysporum f. sp. niveum on the fresh weights and root concentrations of $\mathrm{Cu}$

\begin{tabular}{lcc}
\hline Treatment $^{\mathbf{y}}$ & $\begin{array}{c}\text { Fresh weight } \\
(\mathbf{g})\end{array}$ & $\begin{array}{c}\text { Cu levels } \\
(\boldsymbol{\mu g} / \mathbf{g} \text { of root } \\
\text { tissue }^{\mathbf{z}}\end{array}$ \\
\hline $\begin{array}{l}\text { Noninfested potting mix: } \\
\text { untreated control }\end{array}$ & $9.3 \mathrm{ab}$ & $84 \mathrm{~b}$ \\
$\begin{array}{l}\text { Noninfested potting mix: } \\
\text { NP of CuO }\end{array}$ & $11.7 \mathrm{~b}$ & $107 \mathrm{c}$ \\
$\begin{array}{l}\text { Infested with } F \text {. oxysporum } \mathrm{f} . \mathrm{sp} . \\
\quad \text { niveum: untreated control }\end{array}$ & $8.8 \mathrm{a}$ & $33 \mathrm{a}$ \\
$\begin{array}{l}\text { Infested with } F \text {. oxysporum } \mathrm{f} \text {. sp. } \\
\text { niveum: } \mathrm{NP} \text { of CuO }\end{array}$ & $10.7 \mathrm{ab}$ & $44 \mathrm{ab}$ \\
\hline
\end{tabular}

${ }^{y}$ Plants were infested with dried ground millet inoculum as described in the text; plants were sprayed with 2 to $4 \mathrm{ml}$ of $\mathrm{NP}$ of $\mathrm{CuO}(500 \mu \mathrm{g} / \mathrm{ml})$.

${ }^{\mathrm{z}} \mathrm{Cu}$ was determined by inductively coupled plasma optical-emission spectroscopy following acid digests. with a past study from our laboratory where $\mathrm{CuO} \mathrm{NP}$ were superior to six other NP metallic oxides ( $\mathrm{AlO}, \mathrm{FeO}, \mathrm{MnO}, \mathrm{NiO} \mathrm{TiO}$, or $\mathrm{ZnO})$ in their ability to improve growth of eggplant and tomato grown in soil infested with $V$. dahliae and $F$. oxysporum $\mathrm{f}$. sp. lycopersici, respectively (Elmer and White 2016). In that study, as in the current one, $\mathrm{CuO} \mathrm{NP}$ had a disease-suppressing influence on the host. In the 2015 and 2016 field studies, only $\mathrm{CuO}$ NP produced statistically greater yields when compared with untreated controls $(P=0.02)$. Both commercial $\mathrm{Cu}$ fungicides or bactericides, Kocide 2000 and a $\mathrm{Cu}$ octanoate soap, as well as the corresponding bulk $\mathrm{CuO}$ equivalent, had no effect on disease or yield. The active ingredient in commercial $\mathrm{Cu}$ products is the $\mathrm{Cu}$ ion but it is unclear how $\mathrm{CuO} \mathrm{NP}$ function in plants. The unique size of the NP certainly influences interaction with the infected plants; however, it is not known if $\mathrm{CuO}$ $\mathrm{NP}$ are allowing entry into the plant leaf or if the NP remain in the cuticle and epidermal tissue and serve as a reservoir for slow release of $\mathrm{Cu}$ ions.

$\mathrm{Cu}$ is an essential plant micronutrient that plays a pivotal role in growth as well as defense (Evans et al. 2007; Römheld and H. Marschner 1991; Yruela 2009). Cu is a cofactor for three important proteins: plastocyanins, peroxidases, and multi- $\mathrm{Cu}$ oxidases (Evans et al. 2007). Many of these proteins serve as defense products synthesized in response to pathogenic infection. For example, PPO activity in plants is increased many-fold in the presence of $\mathrm{Cu}$ ions when attacked by pathogens (Evans et al. 2007; Mayer and Harel 1979). These defense reactions are nonspecific and protect plants against a wide array of pathogens. Evans et al. (2007) summarized 70 different disease systems on 30 different crops and found that $\mathrm{Cu}$ suppressed disease in 65 of these instances (93\%). Although it was not clear whether the $\mathrm{Cu}$ effect was as a fungicide or bactericide or by enhanced host resistance, it was noted that, in 30 cases, the disease system involved a soilborne pathogen, which suggests a likely role for mineral nutrition.

Deficiency symptoms of $\mathrm{Cu}$ (stem dieback, chlorosis of leaves, and stunted growth) are very rarely observed on watermelon; therefore, it is assumed that $\mathrm{Cu}$ availability is adequate for normal plant growth in unstressed conditions. Thus, it is important to question why $\mathrm{CuO}$ NP suppress disease. One hypothesis is that, when roots are under pathogenic attack, the level of $\mathrm{Cu}$ needed to activate host defense enzymes may rapidly become limiting. Evidence of this phenomenon was observed in the present study (Table 2). This hypothesis is further supported by the findings of Chmielowska et al. (2010), who found that augmenting soil with high levels of $\mathrm{CuSO}_{4}$ induced PPO, PR1, phenolics, perioxidases, and glucanases in pepper and subsequently increased resistance to $V$. dahliae. The benefits of $\mathrm{Cu}$ fertilization on watermelon in the absence of disease or deficiency symptoms have been documented (Everett et al. 1966). The current work and our previous study (Elmer and White 2016) demonstrate that greater $\mathrm{Cu}$ is present in the roots of plants treated (foliarly)

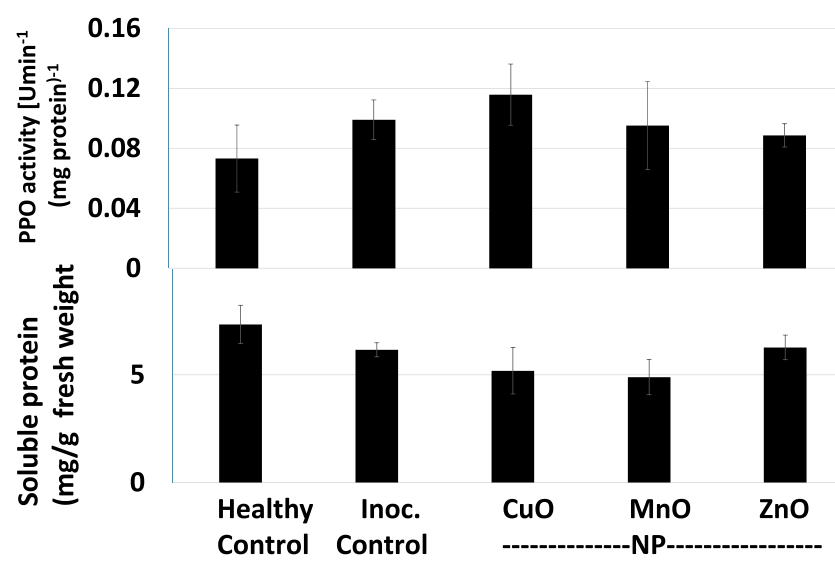

Fig. 11. Levels of polyphenol oxidase (PPO) activity and total soluble protein from roots of watermelon plants treated with foliarly applied applications of nanoparticles (NP) of $\mathrm{CuO}, \mathrm{MnO}$, or $\mathrm{ZnO}$ and grown in soil infested with Fusarium oxysporum f. sp. niveum. 
with $\mathrm{CuO} \mathrm{NP}$ when compared with a corresponding bulk equivalent or untreated plants. Although Wang et al. (2012), Dimkpa et al. (2013a), and Pagano et al. (2016) all reported on the presence of $\mathrm{Cu} \mathrm{NP}$ within exposed plant tissues (upon root exposure), in this study it is unclear whether the NP or dissolved ions from the NP applied to the leaves are actually transported to the root. $\mathrm{Cu}$ is classified as an immobile element (Bukovac and Wittwer 1957), suggesting that the unique size of NP may allow for better transport or dissolution of $\mathrm{Cu}$ ions into the symplast. Additional studies are underway to answer this question.

In the current gene expression experiments, root PPO was strongly upregulated upon exposure to the pathogen and $\mathrm{CuO}$ NP. PPO is strongly associated with enhanced resistance to plant disease (Constabel and Barbehenn 2008; Thipyapong et al. 2004); the enzyme is activated by $\mathrm{Cu}$, (Marziah and Lam 1987), Si (Suriyaprabha, et al. 2014), and both pathogenic and nonpathogenic bacteria (Chen et al. 2000). It is

A

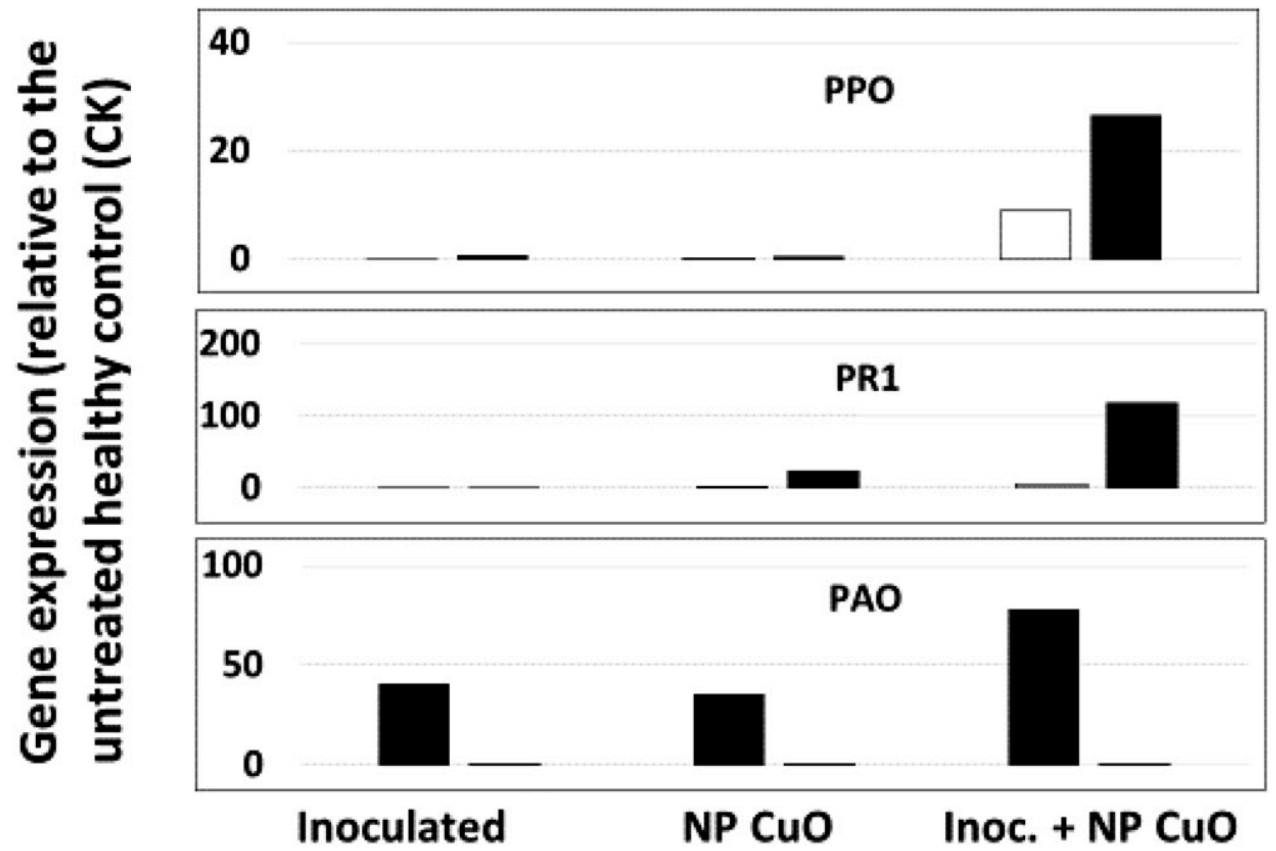

B
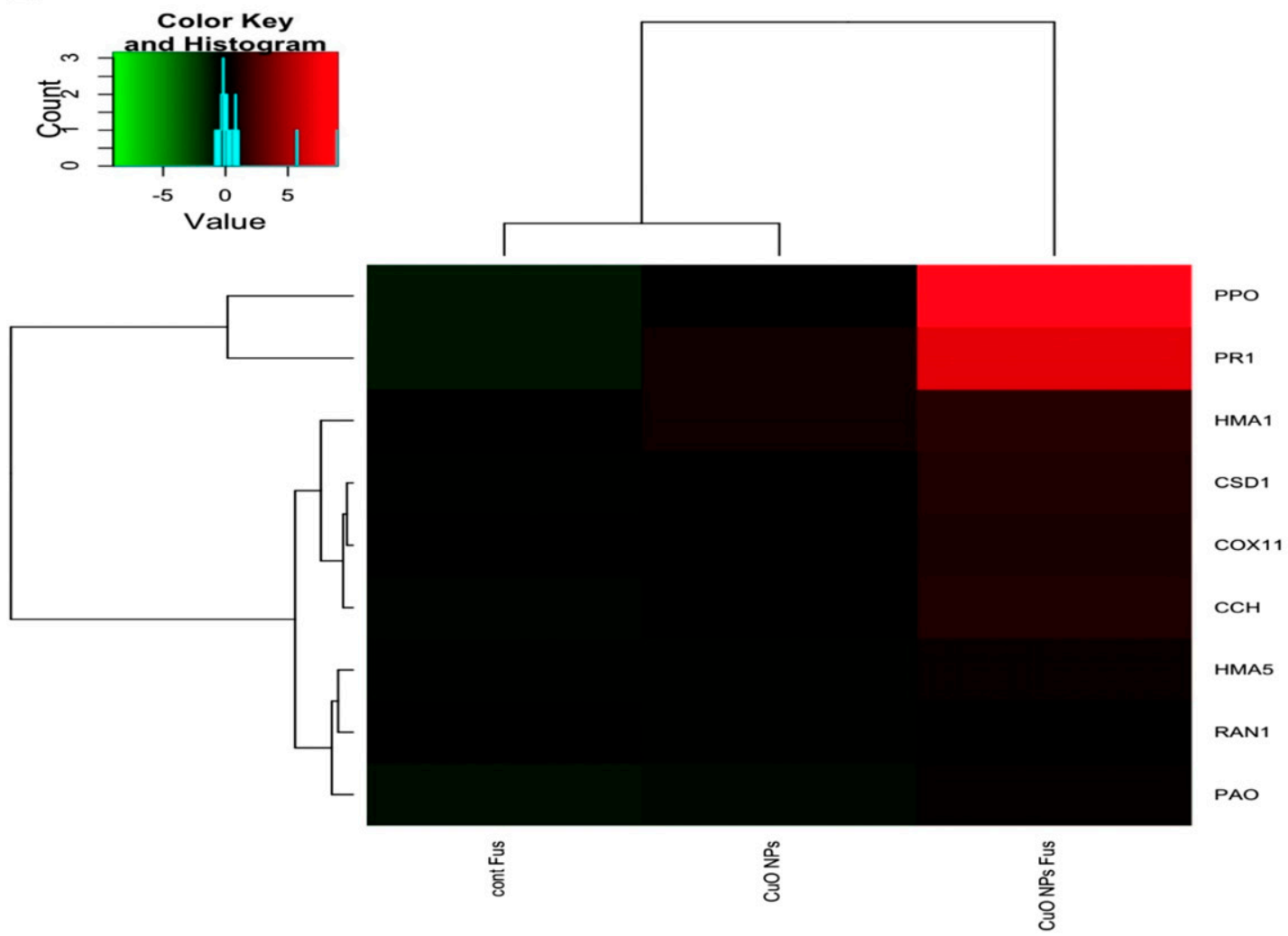

Fig. 12. A, Gene expression levels of polyphenol oxidase (PPO; top), pathogenicity-related proteins (PR1; middle), and polyamine oxidase (PAO; bottom) from roots of watermelon plant treated with or without nanoparticles (NP) of CuO and grown in noninfested soils. Values are based on values from untreated control plant grown in noninfested soil. B, Heatmap response of watermelon roots treated with NP of $\mathrm{CuO}$ and grown in noninfested soils. Values are based on untreated control or soil infested with Fusarium oxysporum f. sp. niveum. Signals were normalized on the untreated control (data not shown). In the heatmap, downregulated genes are reported in green, whereas upregulated genes are shown in red. Genes not significantly different from the expression levels of the untreated control are indicated in black. 
reasonable to assume the $\mathrm{CuO} \mathrm{NP}$ are suppressing disease by enabling the production of phenolic defense barriers through upregulation of this enzyme. Additional confirmation is needed to validate the role of PPO. Future studies should include the extraction of phenolic products and the demonstration that a level sufficient to inhibit $F$. oxysporum $\mathrm{f}$. sp. niveum exists. Although the PPO enzymatic assay found no statistical difference in its activity among the plants treated with $\mathrm{CuO}, \mathrm{MnO}$, and $\mathrm{ZnO} \mathrm{NP}$, collectively, the finding suggests that $\mathrm{CuO}$ NP may offer a novel, safe, and sustainable treatment platform for fungal diseases of important food crops.

Upregulation of the PR1 protein genes was not unexpected, given that these genes are known to be upregulated following pathogen invasion or other stressors. However, it was interesting that the levels were highest in plants treated with both $\mathrm{CuO} \mathrm{NP}$ and $F$. oxysporum f. sp. niveum. Conversely, PAO was strongly upregulated in plants treated with both $\mathrm{CuO} \mathrm{NP}$ or $F$. oxysporum $\mathrm{f}$. sp. niveum. This enzyme catalyzes polyamines; these are metabolites known to accumulate during incompatible interactions between plants and pathogens (Walters 2003). There are several possible roles for polyamines in plant disease, including the hypersensitive response and as an inducer of PR proteins. We do note that NP of other elements have also been reported to increase host defense metabolites. Suriyaprabha et al. (2014) conducted a similar study and found that NP of Si were effective at inducing phenols, phenylalanine ammonia lyase, peroxidase, and PPO in maize, all of which were associated with increasing resistance to Aspergillus spp. The authors also reported particle size dependence, with significantly higher resistance in maize treated with the NP form versus the corresponding bulk equivalent.

One surprising discovery in the current study is that a single or double application of $\mathrm{CuO} \mathrm{NP}$ to young seedlings, often amounting to a total treatment level of less than 1.0 to $2.0 \mathrm{mg} / \mathrm{seedling}$, is associated with increased root $\mathrm{Cu}$ content, season-long pathogen suppression, and yield enhancement. This finding is similar to that reported in our previous study on eggplant and tomato (Elmer and White 2016). One possible explanation for the long-lasting benefits could be that Fusarium root infection occurs on young plants early in the season (Hart and Endo 1981), highlighting the importance of a disease-treatment window. If plant roots have sufficient $\mathrm{Cu}$ availability, host defenses may prevent or minimize infection and delay the onset of symptoms to the extent that disease does not significantly take hold. Clearly, additional research on the role of $\mathrm{Cu}$ in host defense is warranted, as are efforts to optimize disease suppression through alternative treatment regimens and with more well-designed, tunable forms of the NP.

\section{Acknowledgments}

We thank P. Thiel, C. Musante, and S. Younas for technical assistance; and R. Cecarelli, R. Durgy, R. Hannan, and M. McHill for assistance with the field plots.

\section{Literature Cited}

Bradford, M. M. 1976. A rapid and sensitive method for the quantitation of microgram quantities of protein utilizing the principle of protein-dye binding. Anal. Biochem. 72:248-254.

Bukovac, M. J., and Wittwer, S. H. 1957. Absorption and mobility of foliar applied nutrients. Plant Physiol. 32:428-435.

Chen, C., Belanger, R. R., Benhamou, N., and Paulitz, T. C. 2000. Defense enzymes induced in cucumber roots by treatment with plant growthpromoting rhizobacteria (PGPR) and Pythium aphanidermatum. Physiol Mol. Plant Pathol. 56:13-23.

Chmielowska, J., Veloso, J., Gutiérrez, J., Silvar, C., and Díaz, J. 2010. Crossprotection of pepper plants stressed by copper against a vascular pathogen is accompanied by the induction of a defense response. Plant Sci. 178:176-182.

Conover, W. J., and Iman, R. L. 1981. Rank transformations as a bridge between parametric and nonparametric statistics. Am. Stat. 35:124-129.

Constabel, C. P., and Barbehenn, R. 2008. Defensive roles of polyphenol oxidase in plants. Pages 253-270 in: Induced Plant Resistance to Herbivory. A. Schaller, ed. Springer, Dordrecht, The Netherlands.

Dimkpa, C. O., Latta, D. E., McLean, J. E., Britt, D. W., Boyanov, M. I., and Anderson, A. J. 2013a. Fate of $\mathrm{CuO}$ and $\mathrm{ZnO}$ nano and micro particles in the plant environment. Environ. Sci. Technol. 47:4734-4742.

Dimkpa, C. O., McLean, J. E., Britt, D. W., and Anderson, A. J. 2013b. Antifungal activity of $\mathrm{ZnO}$ nanoparticles and their interactive effect with a biocontrol bacterium on growth antagonism of the plant pathogen, Fusarium graminearum. Biometals 26:913-924.

Egel, D. S., and Hoke, S. 2010. Evaluation of triploid watermelon for resistance to Fusarium wilt, 2010. Plant Dis. Manage. Rep. 4:V135.
Elmer, W. H., and White, J. 2016. The use of metallic oxide nanoparticles to enhance growth of tomatoes and eggplants in disease infested soil or soilless medium. Environ. Sci. Nano 3:1072-1079.

Evans, I., Solberg, E., and Huber, D. M. 2007. Copper and plant disease. Pages 177-188 in: Mineral Nutrition and Plant Disease. L. E. Datnoff, W. H. Elmer, and D. M. Huber, eds. American Phytopathological Society, St. Paul, MN.

Everett, P. H., Locascio, S. J., and Fiskell, J. G. A. 1966. Phosphorus and copper effects on growth and yield of watermelons. Vine 3:20-23.

Everts, K. L., and Himmelstein, J. C. 2015. Fusarium wilt of watermelon: Towards sustainable management of a re-emerging plant disease. Crop Prot. 73:93-99.

Hart, L. P., and Endo, R. M. 1981. The effect of time of exposure to inoculum, plant age, root development, and root wounding on Fusarium yellows of celery. Phytopathology 71:77-79.

Jo, Y. K., Kim, B. H., and Jung, G. 2009. Antifungal activity of silver ions and nanoparticles on phytopathogenic fungi. Plant Dis. 93:1037-1043.

Kanhed, P., Birla, S., Gaikwad, S., Gade, A., Seabra, A. B., Rubilar, O., Duran, N., and Rai, M. 2014. In vitro antifungal efficacy of copper nanoparticles against selected crop pathogenic fungi. Mater. Lett. 115:13-17.

Khan, M. R., and Rizvi, T. F. 2014. Nanotechnology: Scope and application in plant disease management. Plant Pathol. J. 13:214-231.

Kim, H. S., Kang, H. S., Chu, G. J., and Byun, H. S. 2008. Antifungal effectiveness of nanosilver colloid against rose powdery mildew in greenhouses. Solid State Phenomena 135:15-18.

Kim, S. W., Kim, K. S., Lamsal, K., Kim, Y. J., Kim, S. B., Jung, M., Sim, S. J., Kim, H. S., Chang, S. J., Kim, J. K., and Lee, Y. S. 2009. An in vitro study of the antifungal effect of silver nanoparticles on oak wilt pathogen Raffaelea sp. J. Microbiol. Biotechnol. 19:760-764.

Komada, H. 1975. Development of a selective medium for quantitative isolation of Fusarium oxysporum from natural soil. Rev. Plant Prot. Res. 8:114-124.

Leeper, G. W. 1952. Factors affecting availability of inorganic nutrients in soils with special reference to micronutrient metals. Annu. Rev. Plant Physiol. 3:1-16.

Marziah, M., and Lam, C. H. 1987. Micronutrients: Polyphenol oxidase from soybeans (Glycine max V. Palmetto) and its response to copper and other micronutrients. J. Plant Nutr. 10:2089-2094.

Mayer, A. M., and Harel, E. 1979. Polyphenol oxidases in plants. Phytochemistry 18:193-215.

Ocsoy, I., Paret, M. L., Ocsoy, M. A., Kunwar, S., Chen, T., You, M., and Tan, W 2013. Nanotechnology in plant disease management: DNA-directed silver nanoparticles on graphene oxide as an antibacterial against Xanthomonas perforans. ACS Nano 7:8972-8980.

Pagano, L., Servin, A. D., De La Torre-Roche, R., Mukherjee, A., Majumdar, S. Hawthorne, J., Marmiroli, M., Maestri, E., Marra, R., Parkash Dhankher, O., Isch, S. M., White, J. C., and Marmiroli, N. 2016. Molecular response of crop plants to engineered nanomaterial exposure. Environ. Sci. Technol. 50:7198-7207.

Ren, L., Su, S., Yang, X., Xu, Y., Huang, Q., and Shen, Q. 2008. Intercropping with aerobic rice suppressed Fusarium wilt in watermelon. Soil Biol. Biochem. 40:834-844.

Römheld, V., and Marschner, H. 1991. Function of micronutrients in plants. Pages 297-328 in: Micronutrients in Agriculture. J. J. Mortvedt, F. R. Cox, L. M. Shuman, and R. M. Welch, eds. Soil Science Society of America, Madison, WI.

Saharan, V., Sharma, G., Yadav, M., Choudhary, M. K., Sharma, S. S., Pal, A., Raliya, R., and Biswas, P. 2015. Synthesis and in vitro antifungal efficacy of Cu-chitosan nanoparticles against pathogenic fungi of tomato. Int. J. Biol. Macromol. 75:346-353.

Servin, A., Elmer, W., Mukherjee, A., De la Torre-Roche, R., Hamdi, H., White, J. C. Bindraban, P., and Dimkpa, C. 2015. A review of the use of engineered nanomaterials to suppress plant disease and enhance crop yield. J. Nanopart. Res. 17:92.

Soffan, A., Alghamdi, S. S., and Aldawood, A. S. 2014. Peroxidase and polyphenol oxidase activity in moderate resistant and susceptible Vicia faba induced by Aphis craccivora (Hemiptera: Aphididae) infestation. J. Insect Sci. 14:285.

Strayer-Scherer, A. L., Liao, Y. Y., Young, M., Ritchie, L., Vallad, G. E., Santa, S., Clark, D., Freeman, J. H., Jones, J. B., and Paret, M. L. 2018. Advanced copper composites against copper-tolerant Xanthomonas perforans and tomato bacterial spot. Phytopathology 108:196-205.

Suriyaprabha, R., Karunakaran, G., Kavitha, K., Yuvakkumar, R., Rajendran, V. and Kannan, N., 2014. Application of silica nanoparticles in maize to enhance fungal resistance. IET Nanobiotechnol. 8:133-137.

Thipyapong, P., Hunt, M. D., and Steffens, J. C. 2004. Antisense downregulation of polyphenol oxidase results in enhanced disease susceptibility. Planta 220:105-117.

Walters, D. R. 2003. Polyamines and plant disease. Phytochemistry 64:97-107.

Wang, Z., Xie, X., Zhao, J., Li, X., Feng, W., White, J. C., and Xing, B. 2012. Xylem- and phloem-based transport of $\mathrm{CuO}$ nanoparticles in maize (Zea mays L). Environ. Sci. Technol. 46:4434-4441.

Wani, A. H., and Shah, M. A. 2012. A unique and profound effect of $\mathrm{MgO}$ and $\mathrm{ZnO}$ nanoparticles on some plant pathogenic fungi. J. Appl. Pharm. Sci. 2:40-44.

Wu, H.-S., Gao, Z.-Q., Zhou, X.-D., Shi, X., Wang, M.-Y., Shang, X.-X., Liu, Y.-D., Gu, D.-L., and Wang, W.-Z. 2013. Microbial dynamics and natural remediation patterns of Fusarium-infested watermelon soil under 3-yr. of continuous fallow condition. Soil Use Manage. 29:220-229.

Yruela, I. 2009. Copper in plants: Acquisition, transport and interactions. Funct Plant Biol. 36:409-430.

Zabrieski, Z., Morrell, E., Hortin, J., Dimkpa, C., McLean, J., Britt, D., and Anderson, A. 2015. Pesticidal activity of metal oxide nanoparticles on plant pathogenic isolates of Pythium. Ecotoxicology 24:1305-1314. 